\title{
Self-Esteem, Contagion Theory dan Suporter Persija Jakarta
}

\author{
Irlandi Paradizsa, Luki Indra Malik, Muhammad Isa, Pangeran Anugrah \\ Mahasiswa Ilmu Komunikasi Fakultas Ilmu Sosial dan Ilmu Politik, Universitas Indonesia \\ Jl. Prof. DR. Selo Soemardjan, Pondok Cina, Beji, Kota Depok, Jawa Barat 16424 \\ irlandiparadizsa@gmail.com luki4554@gmail.com, isalkaf@gmail.com, \\ pangeranralia@gmail.com
}

Masuk tanggal : 02-06-2018, revisi tanggal : 06-12-2018, diterima untuk diterbitkan tanggal : 12-01-2019

\begin{abstract}
This research is aiming to understand behind student motivation upon joining organization such as Jakampus UI that has a stereotype for its tendency towards violence. Within the scope of identity concept, people tends to join a group to be able to shows its identity as a person. This identity, then, become their basis for understanding their own perspective of their dignity and self-esteem. From that, this research also would like to find whether there is a connection between individual concept of self-esteem and the motivation upon joining Jakampus. This research would like to find how the student from University of Indonesia gave meaning and interpret about the supporter of Persija football club which has been attached with some kind of stereotype and the meaning of their membership inside that kind of community. The contagion theory is there to explain about the interpersonal communication process of the member of Jakampus as the effect of its self-esteem fulfilled or not. This research also use qualitative method, using the fenomenology approach. There are several findings that this research has found, which are (1) despite the rampant stereotyping from society towards supporter of Persija such as Jakampus, there is little to no effect of that stereotyping towards their motivation (2) the motivation for student to join Jakampus is to fulfill their self-esteem needs; and (3) the member of Jakampus are affected by the crowds when they are interacting within the organization.
\end{abstract}

Keywords: football fans, self-esteem, contagion theory, stereotype, interpersonal communication

\begin{abstract}
Abstrak
Penelitian ini bertujuan untuk memahami motivasi mahasiswa dalam bergabung dengan organisasi seperti Jakampus UI yang mana distereotipkan karena tendensinya terhadap tindakan kekerasan. Dalam konsep identitas, manusia bergabung dalam kelompok tertentu untuk bisa menunjukan identitas mereka. Identitas ini lah yang kemudian dijadikan sebagai dasar oleh dirinya sendiri dalam melihat harga diri mereka. Berangkat dari situ, penelitian ini berusaha untuk menemukan apakan ada keterkaitan antara konsep self-esteem seseorang dan motivasinya dalam bergabung dengan Jakampus. Artinya, penelitian ini bertujuan untuk bagaimana proses pemaknaan mahasiswa UI terkait dengan pendukung klub bola Persija yang memiliki stereotip tertentu dan makna dari keikutsertaan mereka dalam komunitas pendukung klub tersebut di kampus. Contagion Theory dipergunakan untuk menjelaskan mengenai komunikasi antar pribadi yang terjadi di antara anggota dari Jakampus sebagai dampak dari pemenuhan self-esteem itu terpenuhi atau tidak. Penelitian ini menggunakan metode kualitatif, dengan pendekatan secara fenomenologi. Ada beberapa temuan dari penelitian ini, yaitu (1) meskipun stereotip dari masyarakat terhadap pendukung Persija seperti Jakampus, sedikit bahkan tidak ada efek dari stereotyping tersebut terhadap motivasi mereka; (2) motivasi mahasiswa untuk ikut bergabung dengan Jakampus adalah untuk memenuhi kebutuhan self-esteem mereka; dan (3) anggota Jakampus terdampak dari tindakan kerumunan
\end{abstract}


dalam komunikasi antar pribadi mereka ketika sedang berada di dalam organisasi tersebut.

Kata Kunci: suporter bola, self-esteem, contagion theory, stereotip, komunikasi antar pribadi.

\section{Pendahuluan}

Ketika melihat pemberitaan sepak bola di Indonesia, lebih sering mendengar mengenai sisi negatifnya dari pada sisi positifnya. Kebanyakan dikarenakan perilaku dari para suporter sepak bola yang melakukan tindakan anarkis. Namun, tidak dapat dipungkiri bahwa sepak bola tidak dapat dipisahkan dari para suporternya (Yuwanto, 2014). Tanpa adanya suporter sepak bola, klub tersebut tidak akan bisa mempertahankan eksistensi mereka (Wibawa, 2013). Antara pendukung dan klub sepak bola ada hubungan saling ketergantungan satu sama lainnya. Saling ketergantungan ini didasarkan atas satu kebutuhan yang sama, yaitu prestasi dan kejayaan (Wibawa, 2013)

Salah satu contoh klub sepak bola yang terkenal dan distereotipkan sebagai pendukung yang cukup anarkis adalah Jakmania (Wibawa, 2013). Jakmania adalah sebutan untuk para pendukung klub sepakbola Persija. Persija itu sendiri adalah sebuah klub sepak bola, yang kepanjangannya adalah Persatuan Sepak Bola Indonesia Jakarta. Persija adalah klub sepak bola yang berbasis di Kota DKI Jakarta (Wicaksono \& Prabowo, 2010). Kembali lagi ke organisasi Jakmania, tujuan dari pembuatan organisasi ini adalah untuk menyatukan orangorang yang memang menyukai dan mendukung Persija dan berupaya untuk mengorgnisir para pendukung sepak bola tersebut (Wicaksono \& Prabowo, 2010). Penyebaran suporter dari Jakmania ini tidak hanya sebatas pada bentuk keanggotaannya apakah dia anggota resmi atau tidak, bahkan di setiap daerah pun banyak juga para pendukung-pendukung dari Persija ini, meskipun mereka tidak berasal dari Jakarta. Salah satunya adalah para pendukung Persija di kampuskampus. Mereka yang di kampus pun terkadang memiliki organisasinya sendiri. Kelompok-kelompok yang ada dalam Jakmania tidak hanya terbatas dari Jakampus saja melainkan ada banyak kelompok dan grup lain tapi tidak dapat disebutkan satu persatu. Namun, di dalam penelitian ini, kami memfokuskan kepada Jakmania yang masih berstatus mahasiswa dan tepatnya di Fakultas Ilmu Sosial dan Ilmu Politik (FISIP) Universitas Indonesia (UI) dimana mereka menjulukinya sebagai Jakampus UI. Kelompok kecil ini memiliki aktifitas seperti berangkat bersama-sama dari suatu tempat menuju stadion tempat lokasi pertandingan Persija dan pulang bersama-sama menuju tempat asal. Kelompok The Jak Kukusan (suporter pendukung klub Persija di daerah Kukusan) merupakan salah satu kelompok kecil yang tidak tercatat berdasarkan pembagian kelompok di atas.

Penelitian menemukan bahwa adanya korelasi positif antara self-esteem (harga diri) dengan komitmen seseorang terhadap sebuah tim yang didukung (Sar1, Eskiler, \& Soyer, 2011). Dari penelitian tersebut ditemukan adanya hal yang bisa menjadi penyebab dari paradoks tersebut. Penelitian ini pun dapat dikaitkan dengan teori hirarki kebutuhan dari Maslow.

Oleh sebab itu, penelitian ini berusaha untuk mencari tahu mengenai dukungan yang dilakukan oleh Jakampus UI dilihat dari teori kebutuhan Maslow, yaitu self-esteem (harga diri), juga kaitannya dengan bentuk dukungannya dan 
dikaitkan dengan teori penularan (Contagion Theory) Le Bon. Teori kebutuhan Maslow menjelaskan bahwa salah satu kebutuhan dari manusia adalah kebutuhan akan harga diri (Maslow, 1943). Manusia memiliki hirarki tertentu, dan ketika kebutuhan mereka akan kebutuhan fisik, keamanan, dan cinta telah terpenuhi, maka kebutuhan mereka akan meningkat menjadi kebutuhan akan rasa harga diri (Maslow, 1943). Disini ingin melihat bagaimana mahasiswa FISIP UI yang tergabung dalam Jakampus UI dalam memenuhi kebutuhan akan harga diri mereka dengan menjadi suporter klub bola tersebut.

Studi juga menemukan bahwa adanya sebuah korelasi antara pengalaman dengan bagaimana seseorang berinteraksi dalam komunikasi interpersonal (Sharifirad, Rezaeian, Jazini, \& Etemadi, 2012). Berdasarkan penelitian tersebut, juga ingin melihat bagaimana pengalaman dan pengetahuan mengenai teori penularan dapat membantu mereka yang tergabung dalam organisasi suporter pendukung klub sepak bola Persija untuk terhindar dari dampak negatif dari teori penularan itu sendiri. Maksudnya adalah apakah ada resistensi dari mereka yang sudah mengetahui mengenai dampak dari teori penularan terhadap implementasi teori tersebut pada saat mereka tergabung dalam kerumunan.

Berangkat dari permasalahan-permasalahan tersebut, penelitian ini berusaha untuk mencari tahu mengenai kebutuhan akan rasa harga dalam teori hirarki kebutuhan Maslow terhadap pemilihan Jakampus untuk memenuhi kebutuhan harga diri tersebut. Lalu, penelitian ini pun ingin melihat bagaimana interaksi dan bentuk komunikasi yang dilakukan oleh para Jakampus tersebut yang sudah mengetahui mengenai dampak dari teori penularan kelompok. Maksudnya, penelitian ini ingin mengetahui apakah, meskipun sudah tahu resikonya, mereka yang telah mengetahui dampak dari teori penularan ini tetap bergabung dengan organisasi Jakampus karena kebutuhan mereka atas rasa harga diri, dan mereka telah mengetahui mengenai bagaimana cara menanggulangi dampak dari teori penularan tersebut.

Berdasarkan permasalahan ini, maka rumusan pertanyaan yang berusaha untuk dijawab oleh penelitian ini adalah: (1) Apakah mahasiswa FISIP UI menyalurkan keinginan mereka akan kebutuhan atas rasa harga diri mereka dengan bergabung dalam organisasi Jakampus UI?; dan (2) Apakah mahasiswa FISIP UI yang telah belajar mengenai teori penularan, tetap terkena efek kerumunan ketika sedang berkumpul dengan anggota Jakampus lainnya?

Untuk menemukan kebaruan dari penelitian ini, akan dijabarkan mengenai penelitian apa saja yang pernah dilakukan terkait konsep-konsep yang akan dibahas kali ini. Penelitian-peneitian sebelumnya banyak yang juga telah membahas mengenai fenomena dari sifat agresif dan anarkis dari para supporter klub sepak bola. Ada yang membahas dari segi agresi yang diakibatkan oleh kohesivitas (Agriawan, 2016; Malfaid, 2013; Prakoso \& Masykur, n.d.

Amurwonegoro, 2015 ; Hapsari \& Wibowo, 2015; Hutama, 2015; Safitri \& Andrianto, 2015). Penelitian tersebut lebih membahas kepada aspek kohesivitas sebagai penyabab dari munculnya sikap-sikap agresi dari para suporter sepak bola.

Selanjutnya, ada yang juga mengaitkan fenomena suporter sepak bola yang anarkis ini dengan konsep diri dan motivasi mereka dalam mengikuti klub sepak bola yang terkenal akan anarkinya (Prasetyo, Mahadian, \& Nurhayati, 2016; Handoko \& Andrianto, 2006). Ada pula yang mencoba mengaitkannya dengan teori komunikasi interpersonal di dalam sebuah kelompok yang berdampak terhadap pembentukan aspek kohesivitas mereka (Muliawan, 2013). 
Namun, penelitian yang ini menggunakan pendekatan yang cukup berbeda. Penelitian ini tidak hanya berusaha untuk menemukan motivasi seorang mahasiswa yang sudah mengenyam edukasi, tetapi juga terhadap pilihannya untuk menjadi suporter klub sepak bola sebagai bentuk kebutuhan akan rasa harga diri, dan kaitannya dengan komunikasi antar personal di dalam organisasi dan kaitannya pada teori penularan. Secara ringkas, penelitian ini berusaha untuk menggabungkan beberapa aspek dari penelitian-penelitian sebelumnya, dan mencoba menjelaskan fenomena pendukung klub sepak bola ini secara lebih komprehensif. Lalu perbedaan dan kebaruan dari penelitian ini adalah narasumber atau informan yang lebih muda dan juga lebih berwawasan yaitu, mahasiswa dari Fakultas Ilmu Sosial dan Ilmu Politik Universitas Indonesia. Belum ada yang menjadikan mahasiswa Universitas Indonesia khususnya FISIP UI sebagai narasumber.

Penelitian ini menggunakan teori penularan, dimana masih jarang dan mungkin tidak ada yang menggunakan teori penularan. Karena peneliti menyadari bahwa teori penularan sangat efektif dan berdampak pada kasus yang diangkat ini, karena mereka juga menyadari bahwa mereka juga tertular oleh Jakmania yang lainnnya. Selain teori penularan, ada beberapa konsep lain yang juga dipergunakan dalam penelitian ini seperti konsep mengenai self-esteem oleh Maslow, komunikasi antar pribadi, dukungan terhadap klub sepak bola (dan juga dimensinya yaitu motivasi), serta konsep mengenai stereotip.

\section{Teori Penularan (Contagion Theory)}

Menurut Le Bon (1897) identitas kepribadian masyarakat ditekan pada derajat yang paling rendah ketika mereka berada di dalam situasi crowd (kerumunan). Penularan crowd dapat menghilangkan semua perbedaan kultural dan pendidikan diantara anggota-anggota crowd, mereka direduksi hingga ke common denominator yang paling rendah karena itu kepribadian cenderung direduksi di dalam crowd. Akibatnya individu dalam kerumunan cenderung berperilaku merusak. Mereka dapat berperilaku irasional dan atas berdasarkan insting mereka.

Akibat dari teori penuluaran adalah berkembangnya suggestibility, dimana kerumunan bisa paling cepat menjalar pada khayalan yang paling absurd: kepercayaan melampaui penalaran. Di dalam crowds muncul pemimpin, dalam rangka daya suggestibility, yang dapat memaksakan kehendaknya.

\section{Maslow's Self-Esteem}

Menurut Maslow (dalam Alwisol, 2004), self esteem merupakan kebutuhan manusia yang memerlukan pemenuhan dan pemuasan untuk dilanjutkan ke tingkat yang lebih tinggi. Kebutuhan terhadap self esteem oleh Maslow dibagi menjadi dua jenis yaitu, penghargaan diri dan penghargaan diri dari orang lain. Maslow (dalam Schultz, 1981) juga mengemukakan bahwa jika sesekali seorang merasa dicintai dan memiliki rasa (sense of belonging), maka mereka akan mengembangkan kebutuhan untuk perhargaan (need for esteem). Berbeda dari pengembangan diri (Hariyadi, 2013), harga diri adalah bagaimana seseorang menilai dirinya sendiri. Pengembangan diri adalah cara untuk meningkatkan rasa harga diri. Dalam kaitannya dengan penelitian ini, konsep harga diri atau self-esteem ini berkaitan dengan bagaimana mahasiswa tersebut ikut terlibat menjadi anggota komunitas tertentu sebagai bentuk dari presentasi diri (Purworini \& Nastiti, 2018). Presentasi diri ini, menurut Purworini \& Nastiti 
(2018) berguna untuk agar orang lain bisa memberikan umpan baik dalam proses pembentukan harga diri.

\section{Komunikasi antar Pribadi}

Komunikasi antarpribadi adalah komunikasi antara orang - orang secara tatap muka, yang memungkinkan setiap pesertanya menangkap reaksi orang lain secara langsung, baik verbal maupun nonverbal (Mulyana, 2004). Pentingnya suatu komunikasi interpersonal ialah karena prosesnya memungkinkan berlangsung secara dialogis. Mereka yang terlibat dalam komunikasi bentuk ini berfungsi ganda, masing - masing menjadi pembicara dan pendengar secara bergantian. Dalam proses komunikasi dialogis nampak adanya upaya dari para pelaku komunikasi untuk terjadinya pergantian bersama (mutual understanding) dan empati. Dari proses ini terjadi rasa saling menghormati bukan disebabkan status sosial melainkan didasarkan pada anggapan bahwa masing - masing adalah manusia yang berhak dan wajib, pantas dan wajar dihargai dan dihormati sebagai manusia. Komunikasi interpersonal dibandingkan dengan komunikasi lainnya, dinilai paling ampuh dalam kegiatan mengubah sikap, kepercayaan, opini dan perilaku komunikan. Ketika menyampaikan pesan, umpan balik berlangsung seketika (immediate feedback) mengetahui pada saat itu tanggapan komunikan terhadap pesan yang diontarkan pada ekspresi wajah dan gaya bicara.

\section{Dukungan Terhadap Jakmania}

Dukungan menurut KBBI adalah menyokong, membantu, dan juga menunjang. Dalam konteks penelitian ini, perlu adanya kejelasan mengenai dukungan itu sendiri. Dukungan menjadi sebuah variabel dikarenakan adanya variasi (Sugiyono, 2013) yang dimungkinkan dalam bentuk dan jenis dukungan yang akan diberikan. Bentuk dukungan yang bisa diberikan kepada klub sepak bola bisa dilakukan. Bisa dengan membeli merchandise yang dikeluarkan oleh klub sepak bola tersebut, menonton acara bola secara langsung, atau menyaksikan dari layar kaca atau bahkan aktif bernyanyi dan berkreasi untuk membangkitkan semangat pemain tim kesayangannya (Handoko \& Andrianto, 2006). Jenis-jenis dukungan inilah yang akan menjadi variasi di dalam variabel dukungan terhadap klub sepakbola tersebut.

\section{Motivasi}

Menurut Mannings (2017) ada beberapa faktor yang mempengaruhi seseorang dalam mengikuti organisasi yang melakukan aksi kekerasan secara ekstrim. Ada faktor ekonomi, psiko-sosial, ideologi, dan faktor lainnya seperti faktor paksaan dan faktor kognitif dari individu tersebut. Faktor ekonomi terkait dengan keuntungan yang akan didapatkan oleh calon anggota organisasi tersebut ketika bergabung ke dalam organisasi tersebut. Sedangkan faktor psiko-sosial merujuk terhadap motivasi seseorang untuk tergabung dalam kelompok ekstrim yang melakukan kekerasan adalah dikarenakan beberapa hal seperti ingin merasa aman, ingin mendapatkan akses terhadap alat-alat kekerasan atau memperkuat diri dengan senjata, ingin melakukan balas dendam, atau bisa jadi dikarenakan tidak ingin dikucilkan karena tidak bergabung dalam kelompok tersebut. Faktor ideologis adalah faktor yang berkaitan dengan visi dan nilai yang diangkat oleh organisasi tersebut. Mannings (2017) dalam studinya mendapatkan bahwa organisasi yang memiliki visi yang jelas cenderung akan bertahan lama dalam menjaga anggota untuk tetap bertahan dalam organisasi tersebut. 


\section{Stereotip}

Menurut Oxford Dictionary, stereotip sebagai "widely held but fixed and oversimplified image or idea of a particular type of person or thing." Artinya, stereotip adalah sebagai suatu pandangan yang tetap dan terlalu menyederhanakan tentang seseorang, atau sebuah ide yang diyakini secara luas. Selain itu, Bordalo, Coffman, Gennaiolo, dan Shleifer (2016) menyatakan bahwa stereotip adalah sebagai sebuah konsepsi yang terjadi di berbagai lapisan dan terjadi dimanamana, bisa terjadi terhadap kelompok ras, kelompok politik, gender, demografi tertentu, dan aktivitas-aktivitas tertentu. Ada beberapa stereotip yang akurat dan bisa menjelaskan tentang konsepsi-konsepsi tersebut, namun ada juga stereotip yang tidak selalu benar.

\section{Metode Penelitian}

Pada penelitian ini, jenis penelitian yang akan dilakukan adalah secara kualitatif dan tipe eksplanatori, karena salah satu tujuan dari penelitian ini adalah untuk menjelaskan fenomena yang ada. Pendekatan yang digunakan adalah pendekatan fenomenologi. Pendekatan fenomenologi yang gunakan dalam penelitian ini merujuk pada Creswell (2007) dan Hancock (2002). Menurut Hancock (2002), fenomenologi adalah salah satu bentuk desain penelitian yang berusaha untuk meneliti sebuah fenomena. Hancock (2002) juga menambahkan bahwa apa yang disebut sebagai fenomena itu tidak terbatas pada fenomena saja, tapi juga bisa merujuk kepada kumpulan kejadian, situasi-situasi, pengalaman, atau bahkan konsep-konsep. Penelitian ini mencoba untuk memahami sebuah kejadian atau fenomena yang terjadi pada sekelompok orang. Pada kasus ini, fenomena mengenai dukungan mahasiswa FISIP UI terhadap klub sepakbola Persija.

Subjek dari penelitian ini adalah mahasiswa FISIP UI. Salah satu justifikasi mengapa penelitian ini menggunakan mahasiswa FISIP UI sebagai subjek penelitiannya adalah karena keberagaman di dalamnya. FISIP UI merupakan sebuah kampus yang didalamnya berisikan mahasiswa yang berasal dari berbagai macam suku, budaya, dan latar belakang yang berbeda. Untuk itu, penelitian ini berusaha untuk mencari tahu bagaimana mahasiswa FISIP UI yang memang adalah suporter dari Persija bisa mencinta klub bola tersebut, dan apa yang menyebabkan hal tersebut. Ditambah lagi, untuk karakteristik umur sendiri, tidak dijadikan sebagai sebuah karakteristik yang wajib ada. Melainkan hanya sebagai pelengkap saja. Dikarenakan karakteristik utama yang dicari adalah mahasiswa FISIP UI, tergabung dalam organisasi Jakampus UI, dan pernah mendapatkan mata kuliah Sosiologi yang menjelaskan mengenai teori penularan Le Bon, serta pernah menjadi saksi atau terlibat dalam aksi anarkis para pendukung Persija.

Dalam menentukan siapa yang akan menjadi subjek, penelitian ini menggunakan metode pengambilan sampel secara non-probabilitas (Ritchie \& Lewis, 2003). Hal ini dikarenakan sampel ditarik dengan karakteristik tertentu yang sudah ditentukan sebelumnya. Terlebih lagi, penelitian ini juga tidak berusaha untuk membuat hasil penelitian yang bisa direpresentasikan secara populasi. Oleh sebab itu, teknik penentuan sampel ini dilakukan secara purposif (Ritchie \& Lewis, 2003). Sampel yang karakteristiknya sesuai dengan penelitian ini, akan diambil menjadi subjek penelitian. Dalam penelitian ini, karakteristik yang dipilih adalah mahasiswa FISIP UI, tergabung dalam organisasi Jakampus 
UI, dan pernah mendapatkan mata kuliah Sosiologi yang menjelaskan mengenai teori penularan Le Bon serta pernah menjadi saksi atau terlibat dalam aksi anarkis para pendukung Persija. Selama mereka masuk ke dalam karakteristik tersebut, akan kami jadikan sampel untuk penelitian kami.

Pendekatan yang kami pilih dari penarikan sampel purposifnya itu sendiri adalah dengan menggunakan pendekatan sampel homogen (Ritchie \& Lewis, 2003). Tujuannya adalah untuk mengetahui dan menggambarkan bagaimana fenomena ini terjadi (Ritchie \& Lewis, 2003). Dalam konteks penelitian ini, itu artinya berusaha untuk mencari tahu bagaimana fenomena keberadaan suporter Jakmania itu ada di Kampus FISIP UI.

Dalam penentuan sample framenya dilakukan dengan menggunakan teknik sampel melalui organisasi dan juga snowballing. Pertimbangan dalam menggunakan sampling melalui organisasi adalah karena telah memiliki kriteria tertentu, dan salah satunya adalah keterlibatannya dalam organisasi Jakampus. Penggunaan teknik snowballing juga digunakan untuk mencari sampel-sampel yang cukup unik. Salah satunya, untuk konteks penelitian ini adalah untuk mencari sampel yang pernah terlibat atau menjadi saksi dalam aksi anarkis yang dilakukan oleh para pendukung Persija.

Setelah sampel berhasil dipilih, selanjutnya adalah penentuan dari bagaimana data akan diambil (Ritchie \& Lewis, 2003). Metode pertama pengumpulan data adalah dengan melakukan wawancara mendalam kepada para subjek penelitian yang akan menjadi sampel. Pertimbangannya adalah untuk memahami lebih dalam konteks dari masalah yang sedang dihadapi. Satu orang peneliti akan menjadi pewawancara, dan satu orang peneliti akan menjadi notulis dan juga yang akan merekam data. Selanjutnya penelitian ini akan mengambil data menggunakan teknik observasi (Hancock, 2002). Salah satu alasan dikarenakan ingin mengetahui bagaimana dampak dari teori penularan tersebut kepada mahasiswa FISIP UI tersebut yang tergabung dalam organisasi Jakampus berinteraksi di dalam organisasi juga di dalam kerumunan suporter lainnya.

Dalam penelitian kualitatif, terkadang peneliti juga memiliki peranan dan berpartisipasi langsung di dalam objek yang akan diteliti tersebut (Tracy, 2013). Namun, dalam penelitian ini, peranan peneliti akan diminimalisasi. Penelitian ini berusaha untuk mendapatkan gambaran langsung dari kacamata subjek/sampel penelitian. Sehingga peran dari peneliti disini adalah sebagai pengawas penuh (Tracy, 2013). Untuk bentuk pemahaman yang berusaha diangkat oleh penelitian ini adalah secara emic (pandangan dari subjek yang diteliti) (Tracy, 2013).

Keempat informan dalam penelitian ini adalah mahasiswa aktif Universitas Indonesia. Tiga dari empat informan penelitian adalah suporter aktif Jakampus, lalu satu informan yang tersisa adalaah suporter Persija namun tidak secara official tergabung dalam Jakampus. Semua informan sudah pernah menonton langsung maupun tidak langsung pertandingan klub bola Persija. Berikut adalah profil dari keempat informan:

1. Informan pertama merupakan mahasiswa di FISIP angkatan 2015. Informan pertama dengan inisial "EJ" dan tidak untuk disebutkan jurusannya yang lebih spesifik. Informan yang pertama ini adalah salah satu orang yang aktif di Jakampus dan sangat gemar dan sering menonton Persija Jakarta secara langsung.

2. Informan kedua juga merupakan mahasiswa dari Fakultas Ilmu Sosial dan Ilmu Politik pada angkatan 2015. Informan kedua kami berinisial 'WN.' Usia dari informan kedua kami adalah 21 tahun. "WN" telah tergabung ke 
dalam organisasi Jakampus sejak awal ia masih menjadi mahasiswa baru di FISIP. "WN" adalah salah satu informan yang berhasil didapatkan setelah melakukan teknik snowballing, usai melakukan wawancara dengan informan yang pertama.

3. Informan ketiga berinisial " $R$ " merupakan mahasiswa Universitas Indonesia Fakultas Ilmu Sosial \& Ilmu Politik jurusan Ilmu Antropologi angkatan 2015 yang sedang menjalani kuliah di semester 6 dan berdomisili di daerah Jakarta. Informan "R" sudah menyukai klub bola Persija sejak dulu.

4. Informan terakhir Bernama Ruswan, sama dengan yang lainnya ia juga merupakan Mahasiswa FISIP, dengan jurusan Komunikasi semester 6. Ia bertempat Tinggal di Jakarta. Ruswan merupakan pendukung Persija, namun tidak secara official tergabung dalam JakMania.

\section{Hasil Penemuan dan Diskusi}

\section{Stereotip Terhadap Pendukung Persija Jakarta}

Menurut Informan "EJ" stereotip yang biasanya melekat di Jakmania maupun Jakampus adalah rata-rata mereka suka rusuh dan suka melakukan kerusuhan di jalan maupun di stadion. Saat dulu pun juga suka terjadi keributan antara suporter Jakmania dengan suporter lainnya. Menurut kelompok kami memang sudah berkali-kali terjadi kerusuhan supporter di Indonesia bahkan Jakmania tetapi ini menjadi pembicaraan yang lebih seru dan menarik dengan EJ untuk mendapatkan informasi lebih banyak untuk makalah ini.

"Suka rusuh dan suka membuat keributan dari mulai tempat lokasi ngumpul menuju Gelora Bung Karno dan lain lain itu suka buat rusuh..."

"tapi kalo sekarang sih udah sedikit beda ya, udah ada perjanjian dan petisi perdamainan dengan persib dan supporter nya ya kalo gak damai yaa gabisa lancar lah pertandingan-pertandingan ....."

Informan "WN" sadar mengenai keberadaan dari stereotip yang dilayangkan terhadap para pendukung klub Persija Jakarta oleh masyarakat. Ia pun merasa ketika akan mendukung Persija dengan rekannya yang lain, terkadang masyarakat menilai mereka akan melakukan aksi kerusuhan atau keributan. Namun, informan "WN" menyayangkan hal tersebut, dan menilai bahwa masyarakat yang melakukan stereotip tersebut belum mengerti posisinya sebagai Jakmania.

"Gue kalau lagi pengen nonton.... kadangnya dikira mau ribut, padahal mah mau ke GBK dukung Persija. Dikira mau tawuran ama kampungan lain. Ck.. emang tuh orang orang gak ngerti sih rasanya jadi the jak tuh gimana."

Informan " $\mathrm{R}$ " mengatakan bahwa pandangan orang-orang pada umumnya kepada penggemar bola klub Persija adalah buruk karena membawa dampak negatif bagi orang-orang disekitar.

"Stereotype dari orang-orang awam kepada Jakmania ya seperti destruktif, kayak anarki, dan vandalis .... yang tidak tahu aturan terus kerjanya merusak fasilitas bikin ributt dan bikin ga nyaman pengguna kereta lainnya di stasiun. Suka membajak metro mini. Tapi aslinya, kami tidak seperti itu sih." 
Informan telah mengungkapkan pandangan masing-masing terhadap stereotip fans klub bola Persija. Mereka berpendapat sama bahwa pendukung Persija Jakarta distereotip sebagai pendukung yang anarkis dan juga suka membuat keributan di pertandingan maupun di jalan raya saat mereka kembali pulang atau saat berangkat menonton pertandingan. Tetapi beberapa Informan kami menyampaikan bahwa Jakmania belakangan ini sudah lebih tenang dan tidak separah saat dulu.

\section{Alasan Bergabung dalam Organisasi Jakampus}

Informan "EJ" mengatakan bahwa alasan bergabung dengan organisasi Jakampus dan terjun bersama-sama Jakmania yang lain adalah karena sudah dari kecil dan lingkungannya pun juga mendukung dia untuk ikut Jakmania. Menurut sepengamatan Informan sangatlah melekat dengan Jakmani dan juga Persija Jakarta.

"Orangtua gue juga lahir dari asal Jakarta kan dan gue juga. Lalu juga kan kita harus support local team kita kan yaa berarti itu Persija. Lalu yaaa juga gue suka karena thejak tuh rame dan juga enak-enak lagu lagu nya makanya itu buat kita untuk terus dukung dan untuk nonton langsung juga makanya gue juga jadi persuasi" (EJ)

Informan "WN" mengatakan bahwa alasan dia ikut bergabung menjadi anggota Jakampus di FISIP UI dikarenakan kecintaan ia kepada Persija. Rasa cinta terhadap Persija itulah yang menyebabkan ia memutuskan untuk ikut bergabung juga dalam organisasi pendukung ini, tidak hanya bergabung ke dalam organisasi Jakmania di luar kampus.

"motivasi ikut Jakampus karena saya cinta persija"

"Ya. Persija itu ibarat ibarat jiwa raga guah dan akan mendukung persija terus. Sampe kemana-mana."

Tidak Jauh berbeda, Ruswan menjadi pendukung persija juga karena linkungan masa kecilnya dikelilingi oleh pendukung Persija. Dibuktikan dari kalimat informan sebagai berikut.

"Dulu waktu Masih kecil sering tuh bocah-bocah di kampung ngajakin, ... liat metromini isinya supporter Jakmania. Terus gw (mikir) "hebat juga ya..." (Ruswan)

Dari pernyataan informan, dapat disimpulkan alasan para informan bergabung Jakmania dan juga Jakampus adalah karena memang mereka sudah senang Persija Jakarta dari mereka masih kecil. Lalu berbagai alasan karena memang cinta dan sudah menjadi jiwa raganya mereka untuk terus mendukung Persija Jakarta, Persija juga adalah tim lokal mereka yang patut untuk terus didukung.

\section{Perasaan Ketika Mendukung Persija}

Informan "EJ" menjelaskan bahwa dia sangat senang saat mendukung Persija Jakarta secara langsung dimana dia dapat merasakan atmosfernya. Terutama juga bisa ikut bernyanyi bersama Jakmania yang lainnya. Semenjak mendukung Persija EJ juga dapat mengekspresikan dirinya sendiri dengan cara bernyanyi dan mendukung bersama-sama Jakmania yang lainnya, selain itu dia juga jadi lebih mudah untuk mendapatkan tiket menonton. Hal ini membuat 
dirinya senang karena dapat mendapatkan tiket dari kenalan-kenalan sesama Jakmania dan juga Koordinator dari Jakmania nya.

"kalo nonton langsung lebih seru karena kita bisa liat semua nya dengan jelas dan kita bisa melihat euforia dari pemain dan supporter secara langsung... karena sekeliling kita adalah juga jakmania maka dari itu kita juga pasti akan terpancing untuk ikut nyanyi dan merasakan hal yang sama."

"Tapi semenjak jadi thejak gue juga jadi dimudahin untuk nonton persija secara langsung dan juga gue bisa ngekspresiin diri gue kalau lagi nonton Persija”

Melihat jawaban informan mengenai perasaan mendukung klub bola Persija, peneliti sepakat bahwa Jakmania ataupun Jakampus ini sangatlah senang dan gembira saat menyaksikan dan juga mendukung Persija Jakarta saat bertanding melawan siapapun. Kegembiraan sangat tampak ketika wawancara, dimana mereka semua memiliki jawaban yang hampir serupa dan juga mereka senang saat bersama Jakmania lainnya mendukung tim tercintanya dimanapun mereka berlaga.

\section{Dukungan Terhadap Persija dan Harga Diri}

Informan "WN" menyatakan bahwa mendukung Persija adalah harga diri bagi dirinya. Ia merasa bahwa Persija itu bagaikan dirinya sendiri, sehingga itu sama halnya seperti ia mendukung dirinya sendiri. Ketika ada yang menghina Persija, ia pun merasa layaknya dirinya yang dihina. Merendahkan Persija sama dengan merendahkan dirinya, itulah yang dirasakan oleh informan "WN" terkait harga dirinya.
"(sambil mengunyah makanan) ambil.... Ya. Persija itu ibarat (sambil mengunyah) ibarat jiwa raga guah dan akan mendukung persija terus. Sampe kemana-mana. Makanya di UI gue nyari temen yang persija juga buat supporteran bareng. Buat dukung persija."
"ada lah, kalau menurut gua. Persija itu segalanya. Kalau ada yang ngata- ngatain persija ibaratnya udah nginjek-nginjek harga diri gua."

Informan-informan memiliki jawaban masing-masing terhadap keterkaitan antara dukungan terhadap Persija dan harga diri. Tetapi pada dasarnya jawaban mereka setuju dan meng-iyakan bahwa ada harga diri yang timbul dan berkembang di diri mereka semenjak menjadi Jakmania ataupun Jakampus. Saat mendukung Persija pun juga pasti timbul harga diri dalam diri mereka karena mereka tidak takut pada siapapun saat bersama-sama Jakmania yang lain karena mereka percaya diri dengan harga diri mereka sebagai Jakmania apalagi jika bersama-sama. Para Informan juga menyatakan bahwa mereka mendukung Persija dari hati mereka itu pun terlihat dari ekspresi wajah mereka saat wawancara berlangsung.

\section{Kerumunan dan Perilaku}

Informan pertama kami yang berinisial "EJ" menyampaikan bahwa terdapat beberapa efek yang terjadi saat dia sedang berada di antara kerumunan Jakmania terhadap perilakunya. Terutama terhadap energi saat mendukung dia akan terpengaruh menjadi lebih semangat dan menjadikan semangat untuk terus mendukung bersama-sama.

"kalo dampak ke diri sendiri dari supporter itu berasa banget kayak kalo di stadion kita juga jadi ngerasain sama sama dan juga mendapatkan energi dari seluruh satu stadion itu satu frekuensi dan mendukung bareng-bareng dan jadi 
sama sama ikut semangat dan ikut mensupport pemain yang bertanding di lapangan"

" $\mathrm{R}$ " mengaku saat berada dalam kerumunan perilakunya menjadi melebur bersama masa. Hal ini dibuktikan saat ia menonton di stadion secara langsung. Ia mengatakan bahwa ia ikut-ikutan melakukan tindakan pendukung Persija lainnya yaitu menyanyikan yel-yel, dan menyikapi jalanya pertandingan.

"misalnya kan kemaren nonton nih. Sebenernya ada tempat duduk, Cuma penontonya pada berdiri semua. Ya terpaksa saya ikut berdiri juga. Soalnya kalo sambil nyanyi buat dukung Persija sambil duduk gimana ya, rasanya kurang semangat aja gitu”

Terlihat jelas dari jawaban-jawaban yang tertera diatas. Para Informan memiliki beragam jawaban tapi menurut mereka terdapat efek yang ditimbulkan oleh kerumunan jika sedang menyaksikan Persija Jakarta dan jika hanya bersama Jakmanianya saja. Terlihat dari beberapa jawaban bahwa mereka akan mengikuti gerakan, seperti berdiri bernyanyi bersama. Perilaku kerumunan ini juga terjadi di beberapa informan dimana dia akan sangat aktif dan menjadi diri sendiri jika bersama kerumunan Jakmania yang lain tetapi sebaliknya mereka akan lebih pendiam dan santai jika tidak bersama Jakmania dan mendukung Persija Jakarta.

\section{Pemenuhan Rasa Harga Diri dengan Bergabung dalam Jakampus UI}

Bila melihat dari konsep teori yang dijelaskan di atas (Mannings, 2017), kemudian dikaitkan dengan pendukung Persija. Faktor Ekonomi tidaklah muncul pada fenomena pendukung Persija ini. Tidak ada satupun informan yang menyatakan bahwa mereka menjadi pendukung Persija karena kebutuhan ekonomi. Penelitian menemukan adanya faktor psiko-sosial dan faktor ideologis dari jawaban narasumber dalam mendukung Persija. Hal ini dibuktikan dari jawaban kebanyakan narasumber tentang alasan mereka mendukung persija karena lingkungan kehidupannya, dan masa kecil mereka.

Sesuai dengan penjelasan teori stereotip Baron dan Byrne (1991), maka dari itu tidak jarang bahwa penggemar klub bola persija sering di cap buruk oleh masyarakat umum. Pada sebaliknya penggemar klub bola persija Jakampus membuktikan bahwa mereka tidak melakukan hal-hal buruk seperti itu. hal ini menjadikan motivasi mereka untuk mengubah cara pandang masyarakat umum untuk tidak mengeneralisasikan seluruh fans jakmania. Oleh karena itu faktor tingkat pendidikan sangat berpengaruh pada penggemar klub sepak bola Persija dalam bertingkat. Semakin tinggi pendidikannya maka akan meminimalisir tindakan kericuhan.

Merujuk kepada teori hirarki kebutuhan dari Maslow (1970), manusia memiliki tingkatan kebutuhan, dimana setelah satu tingkat telah tercapai, kebutuhannya akan bertambah. Tingkatan kebutuhan tersebut dimulai dari (1) kebutuhan fisik; (2) kebutuhan keamanan; (3) kebutuhan akan rasa cinta dan perasaan kepemilikan; (4) kebutuhan akan harga diri; dan terakhir adalah (5) kebutuhan akan aktualisasi diri (Maslow, 1970).

Dalam penelitian ini kasus yang diangkat adalah dukungan dari mahasiswa FISIP UI terhadap klub Persija Jakarta dengan bergabung dengan organisasi Jakampus. Bila dilihat terhadap hirarki kebutuhan Maslow, aktivitas dukungan ini masuk ke dalam kebutuhan akan harga diri. Hal ini dikarenakan proses identifikasi diri ke dalam organisasi Jakampus tersebut dapat memberikan rasa keterkaitan yang erat antara anggota Jakampus dengan klub yang 
didukungnya tersebut. Jakampus adalah organisasi yang tujuannya adalah untuk mendukung klub sepakbola Persija. Jakampus itu sendiri mengidentifikasikan dirinya dengan Persija. Jadi, ada beberapa level identifikasi dari anggota Jakampus ke Jakampus, lalu dari Jakampus ke Persija Jakarta, sehingga anggota Jakampus tersebut bisa mengidentifikasikan dirinya dengan klub Persija Jakarta.

Mengenai self-esteem atau kebutuhan manusia yang memerlukan pemenuhan dan pemuasan, kami menemukan dari hasil wawancara yang kami lakukan bahwa hampir semua narasumber merasa harga dirinya naik setelah bergabung bersama Jakampus. Kebutuhan mereka akan dihargai oleh orang lain yang disinggung oleh Maslow dalam teorinya sudah terpenuhi. Hal ini dibuktikan saat mereka mengaku bahwa harga diri mereka naik karena prestasi yang dicetak oleh Persija. Mereka juga merasa menjadi bagian dari keluarga Jakmania yang mana jika dibahasakan oleh teori Maslow sebagai "Sense of Belonging".

Dari proses penelitian yang dilakukan, ditemukan bahwa tiap informan perilakunya berbeda saat berada dalam kerumunan. Khususnya saat mereka menonton di stadion dan menonton langsung. Mereka terbawa suasana dengan ikut menyanyikan yel-yel, berteriak saat gol gagal dicetak Persija, marah saat wasit dinilai tidak adil, dan lain sebagainya. Itu terlihat dari informan yang berinisial EJ dimana ia mengatakan bahwa seringkali dia terbawa suasana dan terbawa apa yang penonton dan Jakmania yang lainnya lakukan, jika saat itu Jakmania melakukan koreografi dan bernyanyi maka EJ otomatis akan mengikuti yang sedang dilakukan. Jadi dari informan EJ saja pun terbukti bahwa terdapat Contagion Theory yang berlaku di kerumunan Jakmania terutama terhadap EJ.

Menurut hasil wawancara dengan informan terjadi perbedaan perilaku dan bentuk interaksi antar personal kepada orang-orang di sekitarnya. Seperti contoh informan " $\mathrm{R}$ " yang mengubah cara komunikasinya di dorong oleh kerumunan dan penularan yang di alami oleh informan ketika berada di lingkungan yang mendukung. Dibuktikan pada ketika informan " $\mathrm{R}$ " berada di lingkungan kampus, informan " $\mathrm{R}$ " menunjukan perilaku pendiam tetapi berbanding terbalik dengan perilaku dan penyampaian komunikasi informan " $R$ " yang lepas dan menjadi diri sendiri (tidak malu-malu) ketika mendukung klub bola persija langsung di tempat pertandingan.

Informan EJ pun menyatakan jika tidak bersama Jakmania sifat dan perilakunya terkadang berbeda ketika sedang bersama Jakmania yang lainnya. Berarti terbukti bahwa memang banyak pendukung Persija atau Jakmania terutama di wilayah Fakultas Ilmu Sosial dan Ilmu Politik memiliki perilaku yang berbeda-beda saat dan tidak saat bersama Jakmania yang lainnya.

\section{Simpulan}

Dari hasil analisis data dan interpretasi data yang telah dilakukan, hasil yang didapatkan adalah: (1) meskipun mahasiswa FISIP UI tahu bahwa persepsi masyarakat, bahkan persepsi mereka sendiri itu, terhadap para pendukung Persija Jakarta itu dikenal dengan tendensi untuk melakukan kerusuhan, hal ini tidak menjadikan mereka enggan untuk bergabung bersama organisasi Jakampus UI; (2) mereka tetap ikut bergabung dengan organisasi Jakampus ini juga dilatarbelakangi oleh keinginan untuk pemenuhan kebutuhan akan harga diri mereka; dan (3) terjadi perubahan sikap dalam diri para anggota Jakampus ketika sedang mendukung Persija Jakarta di dalam kerumunan, dan ketika mereka tidak berada di kerumunan. 
Beberapa hal yang belum dilakukan oleh peneliti untuk penelitian ini adalah untuk menemukan bagaimana dampak dari self-esteem yang didapatkan setelah bergabung dengan organisasi Jakampus. Disini peneliti terbatas hanya meneliti pada motivasi mereka sebagai pemenuhan self-esteem mereka. Padahal ada aspek-aspek lain yang sebenarnya mempengaruhi keanggotaan mereka dalam jangka panjang. Maksudnya ada faktor lain yang menyebabkan mereka untuk tetap bertahan dalam organisasi Jakampus, meskipun adanya stereotip-stereotip tertentu terhadap Jakampus tersebut. Oleh sebab itu, perlu dilakukan penelitian lebih lanjut terkait bentuk self-esteem yang dirasakan oleh anggota Jakampus tersebut, dan dampaknya terhadap keberlanjutan mereka dalam organisasi tersebut.

\section{Ucapan Terima Kasih}

Penulis ingin menyampaikan apresiasi juga rasa terima kasih atas segala bantuan yang telah diberikan dalam proses penyelesaian penelitian ini. Baik itu kepada informan yang bersedia untuk bergabung dalam penelitian ini, juga kepada para pembimbing yang telah memberikan arahan dalam melakukan penelitian ini. Untuk itu semua, penulis ucapkan terima kasih.

\section{Daftar Pustaka}

Agriawan, D. (2016). Hubungan Fanatisme dengan Perilaku Agresi Suporter Sepak Bola. Malang: Universitas Muhammadiyah Malang.

Alwisol. (2004). Psikologi kepribadian Edisi Revisi. Malang: UMM Press.

Amurwonegoro, A. (2015). Perilaku Holiganisme dalam Fanatisme Suporter Sepakbola Indonesia. Surakarta: Universitas Muhammadiyah Surakarta.

Baron, R. A., \& Byrne, D. E. (1991). Social psychology: Understanding human interaction. Boston: Allyn and Bacon.

Baron, R. A., \& Byrne, D. R. (1991). Social Psychology: Understanding Human Interaction, 6th Edition. Boston: Allyn and Bacon.

Bordalo, P., Coffman, K., Gennaioli, N., \& Shleifer, A. (2016). Stereotypes. The Quarterly Journal of Economics, 1753-1794.

Creswell, J. C. (2007). Qualitative Inquiry \& Research Design: Choosing Among Five Approaches. California: Sage Publications, Inc.

Hancock, B. (2002). An Introduction to Qualitative Research. Trent Focus Group.

Handoko, A. T., \& Andrianto, S. (2006). Hubungan Antara Fanatisme Positif Terhadap Klub Sepakbola Dengan Motivasi Menjadi Suporter. Yogyakarta: Universitas Islam Indonesia Yogyakarta.

Hapsari, I., \& Wibowo, I. (2015). Fanatisme Dan Agresivitas Suporter Klub Sepak Bola. Jurnal Psikologi Vol. 8 No. 1 Juni .

Hariyadi. (2013). Buku Pengembangan Diri Islami, Kepengaturan, dan Ideologi Islam. Jurnal Komunikasi Indonesia Vol. Ii (2), 99-109.

Hutama, G. G. (2015). Hubungan antara Kohesivitas Kelompok dengan Perilaku Agresi pada Kelompok Suporter Panser Biru Semarang. Salatiga: Universitas Kristen Satya Wacana.

Le Bon, G. (1897). The Crowd.

Malfaid, I. (2013). Fanatisme Suporter Sepak Bola Untuk Menanamkan Solidaritas Sosial (Studi Kasus Pada Suporter Pasoepati Kartasura). Surakarta: Universitas Muhammadiyah Surakarta. 
Mannings, J. (2017). Individual Factors Motivating People to Join Organized Violent Movements. Kansas: B.S., Franklin University.

Maslow, A. (1943). A theory of human motivation. Psychological Review. 50 (4), 370-396.

Maslow, A. H. (1970). Motivation and personality. New York: Harper \& Row.

Muliawan, T. (2013). Komunikasi Kelompok Suporter Bola Dalam Membentuk Kohesivitas (Studi Kasus Pada The Jakmania UNJ). Universitas Sultan Ageng Tirtayasa.

Prakoso, B. A., \& Masykur, A. M. (n.d.). Fanatisme Suporter Sepakbola Persija Jakarta. 2011.

Prasetyo, E., Mahadian, A. B., \& Nurhayati, I. K. (2016). Konsep Diri Supporter Fanatik Viking Persib Club. e-Proceeding of Management : Vol.3, No.2 Agustus, 2341-2347.

Purworini, D., \& Nastiti, A. D. (2018). Pembentukan Harga Diri: Analisis Presentasi Diri Pelajar SMA di Media Sosial. Jurnal Komunikasi Vol. 10, No. 1, Juli 2018, $33-47$.

Ritchie, J., \& Lewis, J. (2003). Qualitative Research Practice - A Guide for Social Science Students and Researchers. London: Sage Publications.

Safitri, A., \& Andrianto, S. (2015). Hubungan Antara Kohesivitas Dengan Intensi Perilaku Agresi Pada Suporter Sepak Bola. PSIKIS-Jurnal Psikologi Islami Vol. 1 No. 2, 11-23.

Sarı, İ., Eskiler, E., \& Soyer, F. (2011). Does Psychological Commitment to Team Enhance Self-esteem? An Easy Way to Raise Self-esteem. International Journal of Humanities and Social Science Vol. 1 No. 19, 187-196.

Schultz, T. P. (1981). Economics of Population. Reading, Massachussets: Addison - Wesley Publishing Co. .

Sharifirad, G. R., Rezaeian, M., Jazini, A., \& Etemadi, Z. S. (2012). Knowledge, attitude and performance of academic members regarding effective communication skills in education. Journal of Education and Health Promotion Vol. 1, 1-42.

Sugiyono. (2013). Metodelogi Penelitian Kuantitatif, Kualitatif Dan R\&D. Bandung: ALFABETA.

Tracy, S. J. (2013). Qualitative Research Methods: Collecting Evidence, Crafting Analysis, Communicating Impact. Chichester, West Sussex,: WileyBlackwell.

Wibawa, P. A. (2013). Representasi Stereotip Suporter Dalam Film (Analisis Semiotika Stereotip The Jakmania dan Viking dalam Film). Surakarta: Universitas Muhammadiyah Surakarta.

Wicaksono, B., \& Prabowo, H. (2010). Kohesivitas Tim Pendukung Sepakbola Persija. Jurnal Psikologi Volume 3, No. 2, 154-160.

Yuwanto, E. (2014, September 03). Ini Hanya Permainan. Retrieved from Republika.co.id: https://www.republika.co.id/berita/nasional/jabodetabeknasional/17/09/04/sepakbola/liga-dunia/14/09/03/nbav2q-ini-hanyapermainan 